\title{
Landslide Distribution and Processes in the Hills of Central Nepal: Geomorphic and Statistical Approach to Susceptibility Assessment
}

\author{
Motilal Ghimire ${ }^{1}$, Niroj Timalsina ${ }^{2}$ \\ ${ }^{1}$ Central Department of Geography, Tribhuvan University, Kathmandu, Nepal \\ ${ }^{2}$ International Center for Integrated Mountain Development (ICIMOD), Kathmandu, Nepal \\ Email: motighimire@gmail.com
}

How to cite this paper: Ghimire, G., \& Timalsina, N. (2020). Landslide Distribution and Processes in the Hills of Central Nepal: Geomorphic and Statistical Approach to Susceptibility Assessment. Journal of Geoscience and Environment Protection, 8, 276-302.

https://doi.org/10.4236/gep.2020.812017

Received: October 7, 2020

Accepted: December 28, 2020

Published: December 31, 2020

Copyright $\odot 2020$ by author(s) and Scientific Research Publishing Inc. This work is licensed under the Creative Commons Attribution International License (CC BY 4.0).

http://creativecommons.org/licenses/by/4.0/

(c) (i) Open Access

\begin{abstract}
The study examined the landslide distribution, processes, and susceptibility of the Lalbakaiya watershed using GIS and remote sensing technology. Inventory of landslides was done using high-resolution satellite imagery available on Google Earth and was verified and further investigated during the field visit. Geomorphic as well as statistical approaches were applied to assess landslides susceptibility and the significance of their outputs was discussed. Map layers representing conditioning and triggering factors of landslide occurrence were produced from various spatial data sources. The study found that the landslide of the Lalbakaiya watershed is primarily controlled by geology representing young, weak, fragile, and weathered sedimentary rocks. Besides, the role of topography such as steep slope, high relative relief, and land use and land cover played an important role in determining the landslide susceptibility. These processes are triggered by monsoon precipitation, seismicity, and land use change in addition to other factors. The geomorphic approach produces a reliable landslide susceptible map as evidenced by past and present (active) failures on a landscape unit, but this map has low predictability of the landslides occurrence. In contrast, the landslide susceptibility map derived from the landslide index method fairly conforms with that derived from the geomorphic approach. Susceptibility calculated by landslide index map is represented by a pixel value that indicates a probability of landslides occurrence, and is amenable to group into various susceptible classes. The model can predict areas of landslides based on quantitative relation between landslides and geo-ecological factors. The limitation of this approach is that these susceptible areas do not represent clearly defined landscape units,
\end{abstract}


and can also overlook highly erodible areas where landslides are not apparent despite severe erosion and numerous minor failures. The study confirms that both geomorphic and statistical approaches can be complementarily integrated to produce predictable, reliable, and applicable landslide susceptibility maps that can make a plausible planning tool for conservation, development, and disaster risk reduction in the populated slopes of the Himalayas and like.

\section{Keywords}

Landslide, Chure Hills, Susceptibility, Watershed

\section{Introduction}

Landslide is a prominent geomorphic process that has shaped the landscape of the mountains (Korup et al., 2010; Dhakal, 2015). In the tectonically active Himalayas, landslides are the major landscape forming processes. In the populated parts of the mountain, landslides have caused severe damage and destruction to lives and property. In recent times, owing to haphazard infrastructure development, the incidences of landslides have increased, and thus increased the risk.

Landslide refers to the geological phenomena that involve downward and outward movements of slope materials by falling, sliding, and flowing under the influence of gravity (Varnes, 1978; Dikau et al., 1996; Cruden \& Varnes, 1996). Normally, a landslide denotes any down-slope movement of soil and rock under the direct influence of gravity (Highland \& Bobrowsky, 2008). For this study purpose, here it is defined as "the movement of a mass of rock, earth or debris down a slope" (Cruden, 1991).

The mechanism and the causative factors of these processes are attributable to varying characteristics of geology and structure, tectonics, topography, geomorphology, climate, and hydrology (Cruden \& Varnes, 1996; Guzzetti et al., 1999, Dahal et al., 2008) Landslides are the product of a complex interplay of various triggering and conditioning in situ factors. An in-depth understanding of landslide relation to terrain and susceptibility thereby requires various methods, tools, and techniques developed in geomorphology, geology, and engineering.

In Nepal, landslides have been the cause of the major geomorphic disasters that claim numbers of people and huge amounts of property loss. Landslides trigger floods downstream contributing to a huge sediment load in the river. These cascading events contributed to about $40 \%$ of the total population affected by all disasters in Nepal during 1971-2019. Landslide and erosion have been the major cause of land degradation in Nepal (Ghimire, 2020).

The basic requirement for minimizing landslide risk and controlling soil erosion and land degradation is to understand the types and processes of landslides and thereby identifying the areas of landslide susceptibility. Potential sites that are particularly prone to landslides therefore need to be identified. Hence, understanding the landslide processes in the local context and their relation to control- 
ling or triggering factors, and identification of spatially varying landslide susceptible areas has been one of the areas of research in geography and earth science.

Landslide susceptibility map refers to the relative likelihood of future landsliding based solely on the intrinsic properties of a locale or site. It is also known as the "landslide potential map". Evaluation of landslide susceptibility has been carried out through geomorphic and quantitative approaches across the world. In the Himalayas, few studies have applied hazard or susceptibility assessment through geomorphic mapping or landslide inventory methods. Similarly, recently numerous studies have applied quantitative methods of landslide susceptibility and their reliability has been claimed. But the relative advantage in terms of accuracy, predictability, and practicability of landslides susceptibility maps obtained from these approaches to reduce landslides risk and vulnerability has been less studied in the Himalayas.

In this regard, the present study attempts to understand the landslides distribution and processes and analyze the causative factors of landslides in the Lal Bakaiya watershed, central Nepal. This study also intends to prepare a landslide susceptibility map adapting geomorphic and quantitative approaches. Lalbakiya watershed, a fairly densely populated area in the Siwaliks and adjacent slope of the Mahabharata Range in central Nepal is speculated to be a high risk of landslides and flash floods. Landslides disasters are frequently reported during monsoon (DWIDP, 2019). The Master Plan prepared by President Chure Terai Madhesh Conservation Development Board (PCTMCDB, 2017) has identified the Lalbakaiya watershed as one of the highly vulnerable ones in the Siwaliks (PCTMCDB, 2017). Hence, understanding the landslide process and susceptibility zonation of this watershed will be a step forward to identify and implement measures to control landslide and soil erosion processes and reduce disaster risk in the Himalayas. The findings of this study can be replicated to similar geo-ecological conditions elsewhere.

\section{Past studies and approaches}

There exist quite a rich literature on landslide type, processes, and mechanism. The pioneer literature includes (Cruden, 1991; Cruden \& Varnes, 1996; Hungr, Leroueil, \& Picarelli, 2014; Selby, 1993; Terzaghi, 1950; Varnes, 1958) and many that contributed to increased knowledge and understanding of the landslide phenomenon. Similarly, landslide studies carried out in various part of the Himalayas have also added to the existing knowledge (Dahal et al., 2008; Dhital, 2003; DWIDP, 2019; Ghimire, 2001, 2011a; Jaiswal \& van Westen, 2000; Laban, 1979; Miyagi, Gyawali, Tanavud, Potichan, \& Hamasaki, 2004; Pachauri \& Pant, 1992; Wagner, 1983).

Studies on landslide susceptibility range from case studies at the local to the regional scale (Ghimire, 2011b; Youssef et al., 2015; Pradhan et al., 2019; Yang et al., 2019; Trigila et al., 2013). Landslide susceptibility assessment has been carried using two approaches, i.e., qualitative and the quantitative or semi-quantitative approach. Qualitative approaches are, in fact, very subjective insofar as they depend on the knowledge of the experts (Baum, Miyagi, Lee, \& Trofymchuk, 
2014). These approaches utilize the landslide occurrence to classify regions with similar geomorphological and lithological features, indicating high susceptibility to a landslide. Prior failures (from a landslide inventory), morphological evidence, landslides activity, rock or soil strength, and steepness of slope are the more important site factors that determine susceptibility. These factors are key to the geomorphic interpretation of landslide susceptibility.

Quantitative or semi-quantitative methods include various types such as deterministic, bivariate statistical methods, multivariate statistical analysis (Felicísimo, Cuartero, Remondo, \& Quirós, 2013), the analytical hierarchy process (AHP), artificial neural networks (ANN) (Lee, Ryu, Lee, \& Won, 2003; Dou, Yamagishi, Zhu, Yunus, \& Chen, 2018), and others. Many researchers have used bivariate statistical tools such as the certainty factor (CF), statistical index (SI) (Van Westen, Castellanos, \& Kuriakose, 2008), frequency ratio, evidential belief function (EBF), and weight of evidence (WoE). Also, the multivariate method as the logistic regression was applied in several works. The studies carried out in different geological, climatologic, geomorphologic, etc. conditions using statistical tools reveal similar results with good accuracy (Anis, Wissem, Vali, Smida, \& Essghaier, 2019; Park, Choi, Kim, \& Kim, 2013; Pradhan \& Lee, 2010).

One of the objectives of this study is to assess the landslide susceptibility maps produced from afore discussed two categories of approaches, represented here by geomorphic approach and statistically derived landslide index method, and evaluate their applications in reducing landslides risk and vulnerability.

\section{Study Area}

\section{Location}

The study area is the upper catchment of the Lal Bakaiya watershed in central Nepal that covers an area of $868 \mathrm{~km}^{2}$ (Figure 1) and the altitude ranges from 200 - 2115 masl. Physiographically, the watershed can be divided into three major units-Mahabharata Range in the north, Chure Hills (Siwalik Hills) in the South, and Inner valley within Chure hills.

\section{Geology, structure, and landform}

The study area is underlain by the rocks of the Quaternary, Siwalik Group, Pre-Siwaliks, and the Lesser Himalaya formation (Figure 3) (Note: their characteristics are described in the subsequent section). The quaternary deposits or uplifted terrace are the recent lithologies, which underlie the middle part of the watershed. The topography is highly dissected and subdued (internal relief of $99 \pm$ $37 \mathrm{~m} / \mathrm{km}^{2}$ ) and has generally a gentle slope (mean $11 \pm 8$ degree) and is subjected to severe erosion due to rills, gullies, and stream. The rocks are gently dipping towards the north. The Siwalik group consists of three geological units, namely Upper Siwaliks, Middle Siwaliks, and Lower Siwaliks. The Upper Siwaliks consist of poorly consolidated boulders, cobbles, and conglomerates and its geology is therefore highly erodible (Dhital, 2015; Ghimire, 2020). Topography built on the Upper Siwaliks is generally represented by relatively subdued topography 


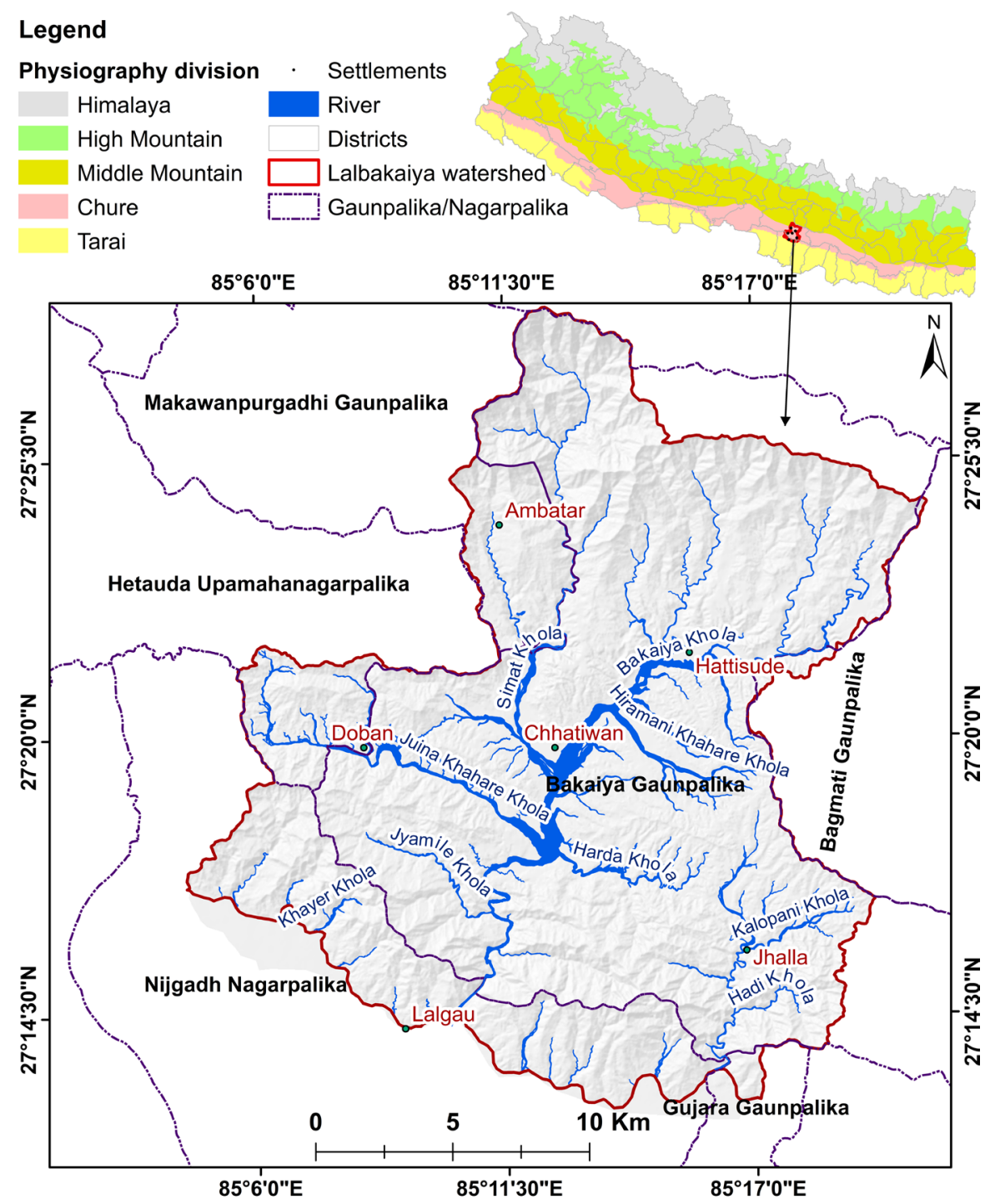

Figure 1. Location of the Lalbakaiya watershed.

(mean relief $158 \pm 73 \mathrm{~m} / \mathrm{km}^{2}$ ) relief and gentle slopes (mean $15 \pm 10$ degree) and highly dissected by streams and gullies. Middle Siwaliks is composed of a higher proportion of sandstone in a sequence of interbedded sandstone and mudstone. The topography is relatively massive and sharp with an internal relief of $290 \pm 84$ $\mathrm{m} / \mathrm{km}^{2}$ (in the southern section) $381 \pm 101 \mathrm{~m} / \mathrm{km}^{2}$ (northern section) and has generally steep slopes, i.e., mean $24 \pm 10$ and $29 \pm 9$ degree respectively. Lower Siwaliks is the oldest of Siwalik formation. It consists of interbedded mudstones and fine sandstones. The ratio of less resistant mudstone is greater than that of sandstone in this formation. The LS is delineated from alluvial deposits of the Tarai plain by the Main Frontal Thrust (MFT) in the south and in the north by Main Churia Thrust lying in the south. The LS, due to the greater proportion of the mudstone bed, has relatively lower internal relief $(253 \pm 74$ and $205 \pm 103$ $\left.\mathrm{m} / \mathrm{km}^{2}\right)$ in the southern and northern sections respectively. The average slope is about $20 \pm 10$ degrees, i.e., less than that of the MS. Sandwiched between the Si- 
waliks, there lie Pre-Siwaliks rocks, which is comprised of fine-to medium-grained sandstone and purple shale. The internal relief is moderate, i.e., $175 \pm 78 \mathrm{~m} / \mathrm{km}^{2}$ with a mean slope of $16 \pm 9$ degrees. The Lesser Himalaya unit lies north of Main Boundary Thrust, which has a stronger relief $\left(1032 \pm 210 \mathrm{~m} / \mathrm{km}^{2}\right)$ with very steep (mean $38 \pm 9$ degree).

The slope in most of the watershed is built mainly on the homoclinal folds with bedrock dipping more or less towards the north in a low to moderate angle ( 25 - 40 degrees) in the south, less than 30 degrees in the middle, and above 50 degrees in the north (Figure 3). On low dipping bedrocks, series of major to minor asymmetric ridges characterizing gentle dip slopes facing north and south-aspect cliffs are formed. These ridges are formed by the tributary streams developed along the strike direction (Ghimire, 2020). On the north of the Marine Khola Thrust, EW and NS symmetric ridges are developed on steeply dipping of bedrock ( $>50$ degrees) of homoclinal structure. The role of thrust and major joints also contributed to the development of this topography. On the south close to MFT and, there is EW trending anticlinal folds which is primarily due to the result of thrusting. The drainage pattern is mainly controlled by joints and faults as well as lithology. In the middle and north part of the watershed, control of lithology and structure are observed, which is reflected in trellis to dendritic drainage pattern. The drainage density is around $5.3 \mathrm{~km} / \mathrm{km}^{2}$ in the Quaternary area, and in the US, the density is $4.33 \mathrm{~km} / \mathrm{km}^{2}$. The MS, LS, and Pre-Siwaliks have a density of $3.5-3.8 \mathrm{~km} / \mathrm{km}^{2}$. In the Lesser Himalayan part of the watershed, the streams have a steep gradient with a denser network, i.e., $4.8 \mathrm{~km} / \mathrm{km}^{2}$. Wide valleys with flood plains consisting of meandered channels are developed on the areas underlain by Quaternary and Upper Siwaliks. Here, the riverbeds of the tributary stream are straight and wide implying a high erosion rate and huge sediment load. The rivers in the Lower and Middle Siwaliks on the southern section are incised and sinuous due to the control of hard sandstone and soft mudstone.

Climate is subtropical to warm temperate below or above 1200 masl. This watershed receives $85 \%$ of rainfall during the summer monsoon. The effect of climate on weathering is high, although the deep weathered layer and soil are not developed as they are washed away by a high rate of erosion on the slopes. Vegetation varies from subtropical evergreen to temperate deciduous forest towards the higher part of the watershed in the north. The population of the watershed is 168,000 (CBS, 2011). During the last six decades, the population density has increased by 6.8 times, which resulted in changes in land use and infrastructure development leading to the intensification of runoff and sediment transportation processes (Shrestha \& Bajracharya, 2013). The north-south Fast Track connecting Kathmandu and Nijgadh and east-west Heatuda-Chatara road also traverse the watershed.

\section{Materials and Methods}

\section{Data types and sources}


For the study, satellite imageries, topographic maps (scale 1:25,000) published by the Survey Department and Geological Maps (scale 250,000) prepared by the Departed of Mines and Geology, Government of Nepal were used. From these data sources, topographic, geomorphology, geology, land use, and land cover were derived.

\section{Inventory of landslide}

The past and present occurrences of landslide are keys to the spatial prediction of future events (Guzzetti et al., 1999). Therefore, the inventory of landslide is the entry point for evaluating the hazard and risk associated with it. In the present study, landslide detection was done by using high-resolution multi-temporal images (2001-2020) provided by Google Earth. The 3D view and the history slicer (allowing to shift to images from different dates) in combination with the relief exaggeration was used to interpret landslides and their type. The morphological signatures representing various types of landslides were identified with the help of shape, size, texture, color, topographic location, vegetation characteristics revealed in an image vis-a-vis expert judgment. Similarly, the interpreted landslides were verified and their characteristics and association with geomorphology, geology, and structure were examined during the field visit. Altogether 828 landslides were inventoried, out of which 798 were used for assessing susceptibility using a statistical model and the rest were used for validation.

\section{Geomorphic assessment of the landslide and erosion susceptibility}

Geomorphic interpretation of landslides and erosion susceptibility was done following the basic principles: 1) The past and present is key to the future (Hutton, 1788; Varnes, 1978), 2) Past landslides and erosional processes leave discernible morphological features on the terrain, and 3) Similar biophysical conditions produce similar phenomena (Guzzetti et al., 2012). From the location of active landslides, similar landslides did occur or not in the past were investigated.

This approach relies on the geomorphic footprints of landslides and erosion both currently active and old types. It tries to identify the landscape unit where landslide occurrence was frequent in the past and present and are likely to occur in the future (Figure 2). Such landscape units comprise of past and present failures, a similar rock or soil strength, slope steepness, and aspect. Inventory of the observed fresh and old landslide morphology, runout deposits or fan, and identification of the landscape units of repeating topography and geomorphology, where footprints of landslides are frequent are the main components of this approach.

\section{Statistical approach of landslide susceptibility mapping}

The basic underlying principle of determining landslide susceptibility is "Landslides do not occur randomly, or by chance (Guzzetti et al., 2002; Crozier, 1986). Slope failures are the result of the interplay of physical processes, and mechanical laws against the controlling and triggering factors determined the stability or failure of a slope". These physical phenomena, which control the landslide occurrence in various size and types in space and time, can be applied to determined landslide susceptibility using statistically and other quantitative methods of derived relation. 


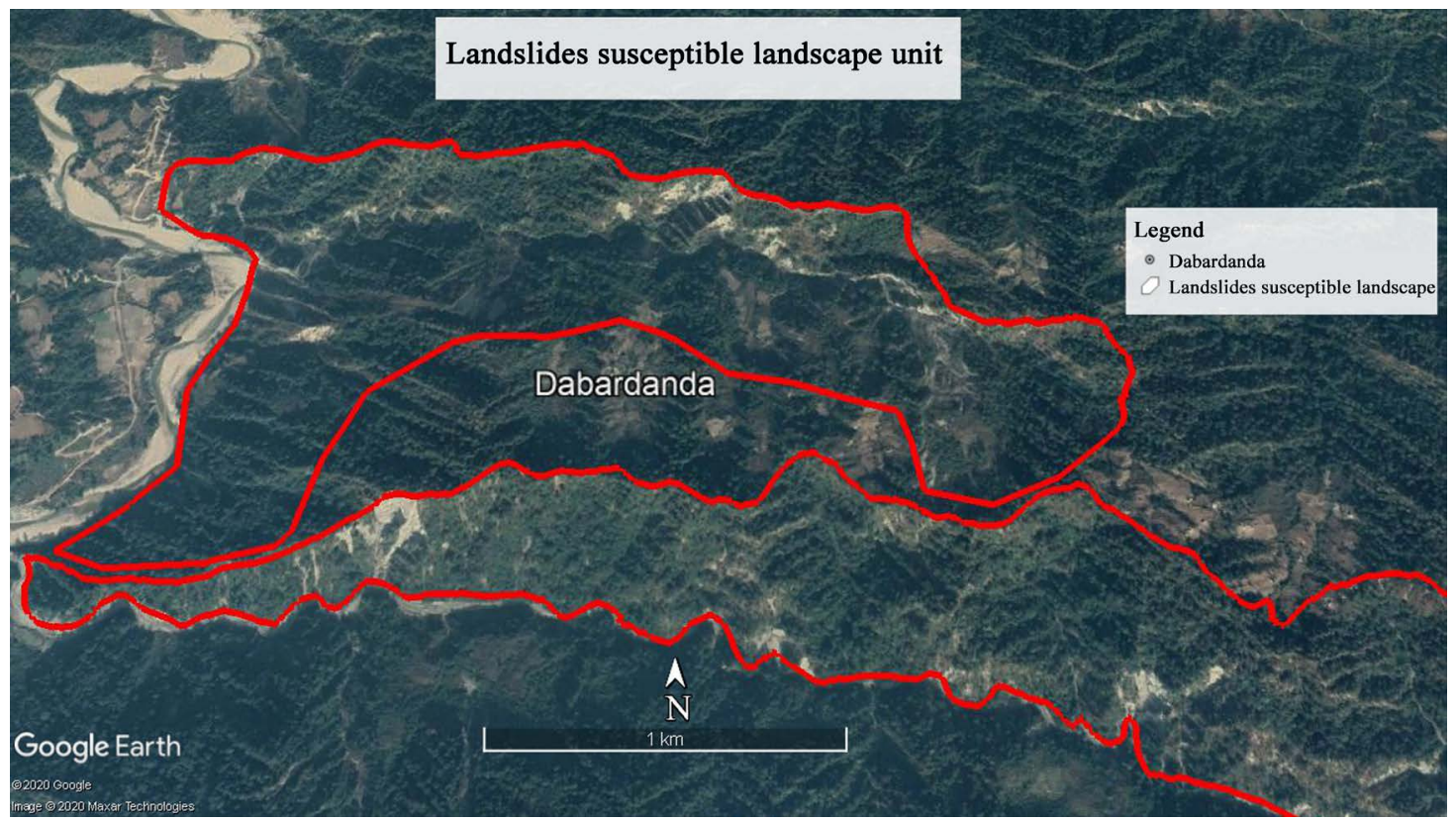

Figure 2. Geomorphic approach to the identification of landslide susceptible landscape unit.

The statistical approach is well-known and widely used for landslide susceptibility mapping (Van Westen, 2000; Ghimire, 2001; Dahal et al., 2008; Park et al., 2013; Reichenbach et al., 2018; Pradhan et al., 2019; Zhang et al., 2020). This statistical model is simple and flexible to use and provides an accurate result (Ghimire, 2001; Mandal \& Mondal, 2019; Pradhan \& Lee, 2010; Van Westen et al., 2008). This model calculates landslide susceptible areas in a GIS environment based on the calculated weights of the multiple class of every factor that has a role in conditioning or triggering landslides. Various studies have established that landslide susceptible is conditioned by inherent in situ terrain factors, which comprise geology, topography, soil, and hydrology. Besides, the rainfall and tectonic driven seismicity trigger landslides. Human manipulation of land use and land cover, mining and excavation, and haphazard construction of infrastructures also induce landslide occurrence (Ghimire, 2011b; Guzzetti et al., 1999; Deoja \& Thapa, 1991; Dhital et al., 1991). Therefore, this study intends to incorporate the aforementioned factors that influence landslide occurrence. These factors are broadly categorized into four domains: i) Geology ii) Topography (aspect, relief range, slope gradient, solar illumination, slope shape, and topographic position index), iii) Hydrology(annual rainfall, drainage density, and topographic wetness index), iv) Anthropogenic (land use and land cover).

A statistical analysis, called the landslide index method, was used for calculating landslide susceptibility, which has proved to be very efficient in landslide prediction (Pradhan \& Kim, 2014). In this method, the role of each landslide triggering and conditioning factors were analyzed with existing landslides, thereby landslide susceptibility weights for each factor class were calculated. The weightage might be different for different classes of a factor since they have a different impact on landslide occurrence. A weight-value for a factor class, such 
as a certain lithological unit or a certain slope class is defined as the natural logarithm of the landslide density in the class divided by the landslide density in the entire map (Van Westen, 1997):

$$
W_{i}=\ln \left(\frac{\text { Density class }}{\text { Density map }}\right)
$$

where,

$W_{i}=$ Calculated weight of certain factor class.

Density Class $=$ the landslide density of each factor class.

Density Map = the landslide density in the entire map.

Ln= Natural logarithm.

Landslide susceptibility index (LSI) is determined by the summation of the weight of multiple class of each factor using an equation (Lee \& Pradhan, 2006).

$$
L S I=\sum_{i=1}^{N} W_{i}
$$

where $W_{i}=$ Weight calculated for classes of each $i$ factor

$N=$ Total number of factors

Then, LSI map was reclassified map into five categories of landslide susceptibility zones, i.e., very low, low, moderate, high, and very high.

The validation of the landslides map was done by evaluating the success rate concerning those landslides of the inventory that were not used in the model.

\section{Result and Discussion}

\section{Landslides distribution, process, and mechanism}

The total number of landslides in the watershed is 828 with an average area of $0.6 \pm 0.06 \mathrm{ha}$ (Figure 3 ). The distribution of landslides depicts that landslides are not random in occurrence rather they are controlled by in situ factors which are discussed in the coming sections. These landslides provide insight into the mechanism of landslides in the study area. The distribution, type, and mechanism of landslide and their processes vary according to the variation in geology, structure, and topography. Huge landslides including rockfalls and rockslide are common in the steep south-facing slope of Pakthali and Jyamile Khola, and Kaileni Khola areas in the southern part of the watershed. The size of this landslide range from 0.29 to $11 \mathrm{ha}$, with an average of $1.01 \pm 1.5 \mathrm{ha}$.

The terrain is underlain by the Middle Siwaliks that comprise easily erodible mudstone between thick sandstone beds. Rapid weathering followed by speedy erosion in the mudstone bed compared to a resistant massive sandstone bed leads to loss of support own load and thus results in rockfall or rockslide or complex slide. The intersecting joint sets with fractures on the high angle slope form wedges that favor the initiation of rockfalls and other types of landslides. Similar failures are common in south-facing steep slopes and antidip escarpments of Lal Khola hillslopes in the southwest and Bamara Khola, Bagar Khola, the southern catchment of Dhansar Khola and other minor tributaries 
in the southeast. The size of the landslides is large than other parts of the watershed, i.e., a range of 0.26 - 31 ha with an average of $2.2 \pm 4.59$ ha. The aforementioned areas are close to the Main Frontal Thrust, a zone of neotectonic activity, which is represented by sheared and fractured rocks that make the favorable site for weathering and landslides including shallow slides and debris flow (Figure 3). In the weathered and gentler dipslope of these areas, various failures viz. shallow, planar failures including wedge failures were also encountered. Similarly, along the steep sides of the narrow valley incised by the Bakaiya River in the south, rockfalls, wedge failures, and debris flow from the high angle slopes were observed. Several landslides were initiated by toe erosion at the convex bends of the main river and tributaries. The east-west tributary streams are developed long the strike direction in MS and Upper Siwaliks in the south part of the Bakaiya watershed have produced very steep antidip slopes, where rockfalls and cliff erosion are common leading to the cliff retreat.

Similarly complex to rotational slides of moderate to small size (up to 3 ha

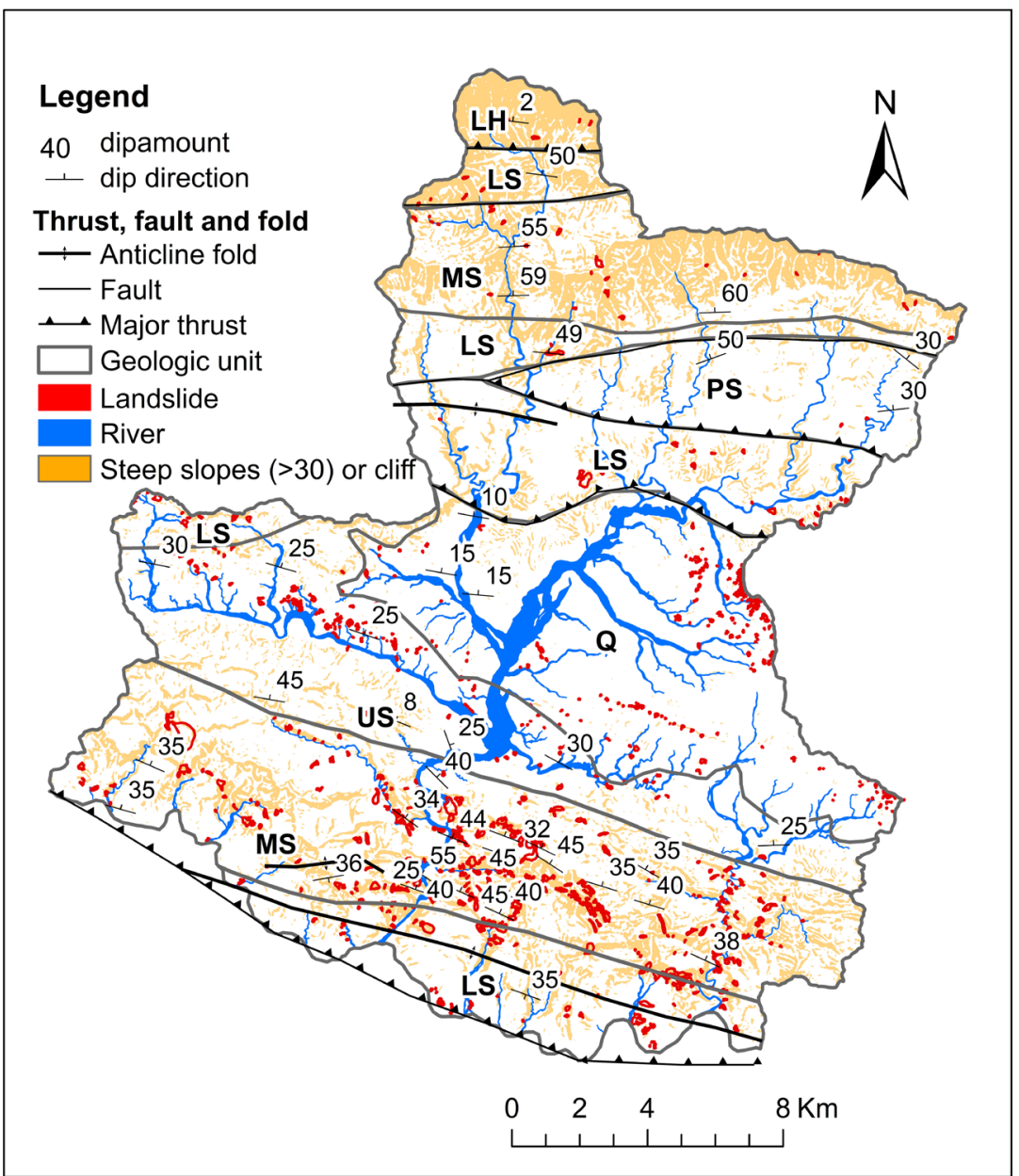

Figure 3. Landslide distribution with respect to geology, structure, and steep topography. Q: Quaternary, US: Upper Siwaliks, MS: Middle Siwaliks, LS: Lower Siwaliks, PS: Pre-Siwaliks, LH: Lesser Himalaya. 
and an average of $0.27 \pm 0.43 \mathrm{ha}$ ) were observed in the upper catchment of the Jiune Khahare Khola in the west of central part of the watershed. Shallow slides and debris flow, and erosional scars forming gullies and ravines are widespread in the Upper Siwaliks and Quaternary uplifted terraces in the central part of the watershed. The average size of these failures is $0.28 \pm 0.41$ ha with a maximum of 3 ha.

Landslides with large rock fragments mixed with soil and weathered materials are frequent in the Middle Siwaliks (Table 1, Figure 3). This is because this zone consists of thickly bedded medium to coarse-grained relatively resistant sandstone alternating with thinly bedded mudstones which are very weak and highly susceptible to physical weathering. The joints spacings are relatively close in sandstone which allows for the production of angular rock fragments in landslide debris. This provides differential weathering conditions between the sandstone and mudstone layers. High grade of weathering followed by erosion of the highly erodible mudstone layers eventually may not support sandstone beds, which may lead to the bedrocks move down the slope (Figure 3 ). The results are similar to Bhandari \& Dhakal (2018), who have assessed lithological control on a landslide in the Babai Khola watershed, Siwaliks zone of Nepal. Further, sandstone and mudstone owing to differing permeability and porosity enhance the activity of water on more permeable beds to create additional load causing slope failure.

Besides, the steep slope and high relief developed on resistant thick-bedded sandstone in the Middle Siwalik have increased shear stress against shear strength in the slopes (Terzaghi, 1950; Varnes, 1978; Dhakal, et.al, 2014; Dhital, 2015). Hence the slope failures such as rockslide, rockfall, and complex movements are common (Ghimire, 2011b).

Lower Siwalik consists dominantly of weak beds of mudstones that are highly weathered or have converted to residual soil after the complete weathering. Weathered materials move easily downslope, especially during intense rainfall. Owing to the low permeability of the rocks, water cannot easily infiltrate deeper, remain within the soil mass. The saturated soil mass exerts pore water pressure.

Table 1. Landslide distribution in different geological units.

\begin{tabular}{cccccc}
\hline Geological division & Area $\left(\mathbf{k m}^{2}\right)$ & \multicolumn{4}{c}{ Landslide occurrence } \\
\cline { 3 - 5 } & & area $\left(\mathbf{k m}^{2}\right)$ & $\%$ area & count & $\%$ count \\
\hline Quaternary Deposits & 99.0 & 1.02 & 19.2 & 224 & 28.1 \\
Upper Siwaliks & 56.9 & 0.73 & 13.7 & 143 & 17.9 \\
Lower Siwaliks & 90.4 & 0.98 & 18.4 & 106 & 13.3 \\
Middile Siwaliks & 141.4 & 2.51 & 47.2 & 317 & 39.7 \\
Pre Siwaliks & 30.1 & 0.04 & 0.8 & 3 & 0.4 \\
Lesser Himalaya & 7.6 & 0.04 & 0.8 & 5 & 0.6 \\
\hline
\end{tabular}

Source: Geology (DMG, 2007) and Landslides (Image interpretation and field survey). 
This pressure also triggers landslides in the form of earth slides, debris slides, and rock slides. Shallow landslides and surface erosion are also common features in this formation.

In the middle part of the watershed underlain by Upper Siwaliks, conglomerate rocks are present which are made by the consolidation and cementation of rock fragments and fine sediments, gravel, sand, and silt (matrix). This geological formation is easily eroded, and overlain topography is highly dissected, and consists of subdued relief. Different degree of cementation allows a varying degree of erosion within the same rock mass. During rainfall, weathered and weak cementing material (clay and calcite) in conglomerate and the thin layer of mudstone between conglomerate beds get eroded. This causes debris slide and flow, block fall, and moderate to severe gully formation leading to flash flood in rivers.

The topography formed on Quaternary deposits encounters mass movement problems caused by gullies, bank erosion, and surface erosion. Because of the lack of cementation and consolidation of sediments, the hills are very fragile and sediments of these hills can easily move downslope in the form of debris fall, flow, and slide. Large ravines due to gradual erosion processes are developed appearing like landslide scars.

Pre-Siwaliks constitute relatively uniform and strong beds of sandstone with only slight physical weathering and probably fewer landslides are observed. The northernmost part of the watershed is underlain by the Lesser Himalayan rock comprising Pre-cambrian metasedimentary and metamorphic rocks (undifferentiated) (DMG, 2007). Landslides are less frequent in space compared to the Siwaliks. Rockfall on the steep slopes as well as debris flow and shallow landslides are observed on the weathered rocks of the area. The average size of slope failures is $0.52 \pm 0.69$ ha with the largest one of $3 \mathrm{ha}$.

Apart from weathering, faults, intricate joints, and fractures also play a prominent role in the occurrence of landslides in the Siwaliks. Through the joints, water enters deeper into the rocks that exert pore pressure which reduces the sheer strength and triggers landslides through the plane of weakness (Selby, 1993).

\section{Landslide conditioning and triggering factors}

Landslide causes are diverse and have been recognized by several authors Terzaghi, 1950; Varnes, 1978; Crozier, 1986; Brunsden et al., 1975; Cruden \& Varnes, 1996. Broadly, these factors can be divided into two types, i.e., a) conditioning factors and $b$ ) triggering factors determine the inherent shear strength of the slope. They control the binding and frictional force of the slope (Selby, 1993). Internal changes or disturbance in the in-situ factors can lead to a reduction of the shear strength and may induce landslides and erosion. Various studies have established that landslide occurrence is conditioned by inherent in situ terrain factors, which comprise geology, topography, soil, hydrology, and land use. External factors that reduce the internal strength of the conditional factors and trigger slope failures are triggering factors. These triggering factors are var- 
ied, i.e., groundwater, rainfall, seismicity, land use change, and other human activities that disturb slope stability.

The following conditioning and triggering factors are considered in the study (Table 2).

\section{1) Topographic}

Slope: The slope gradient represents the downhill component of the force. This force is high on the steeper slope which induces gravitational shear stress on slope materials to induce slope failure (Dai et al., 2001; Chapin et al., 2002). However, slopes in combination with the slope material cohesion, angle of respose, and moisture conditions normally determine slope stability conditions; therefore, the gentler slope may also render the landslides, particularly in colluvial or deeply weathered slopes (Selby, 1993). In the study area, landslide density has increased with slope steepness. The steep slopes of the Middle and Lower Siwaliks of the Lalbkaiya are related to the landslide occurrence and affecting both in area and frequency, which is also recognized in other parts of the Chure hills (Ghimire, 2001; Ghimire, 2011b).

Relative relief: It reflects the local difference in height within a unit area. As other parts of the Chure hills, relative relief has shown a significant association with the landslide in Lalbakaiya (Ghimire, 2011a). The threshold local height beyond where the probability of the observed landslide increases around 50 $\mathrm{m} / 2.5 \mathrm{ha}$ (Ghimire, 2011b). Potential energy required for erosion and mass movement in general increases with increased local elevation. High relative relief can be both cause and consequence of the landslides and erosion in the sedimentary rocks of the Siwaliks (Table 2). However, in the Upper Siwaliks and quaternary, although relative is low and subdued, deep gullies and streams are observed indicating high erodibility of rock. Deep and sharp erosional scars appearing landslides are very common in the areas of Upper Siwaliks and raised Quaternary deposits.

Aspect: It is related to parameters such as the orientation of geological discontinuities controlling landslides, precipitation, wind impact, and sunlight exposure (Ercanoglu et al., 2004). Landslide distribution on various slope aspects is revealed in Table 2. Landslides seem to prevail in the south-facing slopes of the asymmetric ridges which are normally very steep and also on similar slopes in the northern part of the watershed.

Slope shape: It has a strong influence on slope stability. The shape of the slope act as a flow converging or dispersing surface, and a primary determinant of subsurface water in the hillslopes. There are three basic slope units: a) convex, b) planar, and c) concave (Table 2). Generally, convex slopes are more stable as they disperse the runoff more equally down the slope, whereas concave slopes are considered potentially unstable because they concentrate water at the lowest point and contribute to the buildup of adverse hydrostatic pressure (Stocking, 1972). A similar condition was found in Lalbakaiya, where landslide density was high in the concave slope. 
Table 2. Conditional and triggering factors, and landslide occurrence.

\begin{tabular}{|c|c|c|c|c|c|c|}
\hline Domain & Factors & Classes & Area $\left(\mathrm{km}^{2}\right)$ & Landslide (ha) & $\begin{array}{l}\text { Landslide density } \\
\left(\mathrm{ha} / \mathrm{km}^{2}\right)\end{array}$ & Weight \\
\hline & & $<15$ & 156.7 & 88.4 & 0.56 & -0.80 \\
\hline & & $15-25$ & 131.9 & 141.76 & 1.07 & -0.15 \\
\hline & Slope (Degree) & $25-35$ & 94.0 & 157.4 & 1.67 & 0.29 \\
\hline & & $35-45$ & 36.5 & 104.4 & 2.86 & 0.83 \\
\hline & & $>45$ & 5.8 & 40.76 & 7.06 & 1.73 \\
\hline & & $>10$ & 103.9 & 44 & 0.42 & -1.09 \\
\hline & & $10-20$ & 130.2 & 121.84 & 0.94 & -0.29 \\
\hline & Relief (m/100m) & $20-30$ & 110.6 & 146.6 & 1.32 & 0.06 \\
\hline & & $30-40$ & 61.8 & 134.88 & 2.18 & 0.55 \\
\hline & & $>40$ & 18.8 & 85.8 & 4.57 & 1.29 \\
\hline & & North & 43.3 & 65.84 & 1.52 & 0.19 \\
\hline & & North east & 47.4 & 40.84 & 0.86 & -0.38 \\
\hline & & East & 49.1 & 34.92 & 0.71 & -0.57 \\
\hline & 1 & South east & 61.2 & 59.92 & 0.98 & -0.25 \\
\hline & & South & 57.3 & 78.64 & 1.37 & 0.09 \\
\hline \multirow{18}{*}{$\begin{array}{l}\text { Topographic \& } \\
\text { Morphometric }\end{array}$} & & South west & 63.0 & 98.28 & 1.56 & 0.22 \\
\hline & & West & 56.2 & 83.16 & 1.48 & 0.17 \\
\hline & & North west & 47.4 & 71.12 & 1.50 & 0.18 \\
\hline & & Concave & 183.6 & 306.88 & 1.67 & 0.29 \\
\hline & $\begin{array}{c}\text { Curvature (Slope } \\
\text { shape) }\end{array}$ & Flat & 65.4 & 38.4 & 0.59 & -0.76 \\
\hline & & Convex & 175.8 & 187.44 & 1.07 & -0.16 \\
\hline & & Deeply incised river or stream & 45.9 & 104.12 & 2.27 & 0.59 \\
\hline & & Open slope or river valley & 148.9 & 152.64 & 1.03 & -0.20 \\
\hline & $\begin{array}{l}\text { Topographic } \\
\text { position }\end{array}$ & Footslope & 123.1 & 164.84 & 1.34 & 0.07 \\
\hline & & Midslope & 81.1 & 81.8 & 1.01 & -0.22 \\
\hline & & Upper slope or ridge & 25.9 & 29.32 & 1.13 & -0.10 \\
\hline & & $<80,000$ & 20.4 & 62.12 & 3.04 & 0.89 \\
\hline & & $80,000-95,000$ & 55.2 & 112.92 & 2.04 & 0.49 \\
\hline & $\begin{array}{l}\text { Solar radiation } \\
\qquad\left(\mathrm{W} / \mathrm{m}^{2}\right)\end{array}$ & $95,000-105,000$ & 87.1 & 146.16 & 1.68 & 0.29 \\
\hline & & $105,000-115,000$ & 154.8 & 140.8 & 0.91 & -0.32 \\
\hline & & $>115,000$ & 107.2 & 70.72 & 0.66 & -0.64 \\
\hline & & $<2100$ & 8.1 & 3.72 & 0.46 & -1.01 \\
\hline & & $2100-2150$ & 18.5 & 17.44 & 0.94 & -0.28 \\
\hline \multirow[t]{3}{*}{ Hydrology } & Rainfall (mm/yr) & $2150-2200$ & 82.5 & 100.08 & 1.21 & -0.03 \\
\hline & & $2200-2250$ & 239.8 & 297.24 & 1.24 & -0.01 \\
\hline & & $>2250$ & 76.4 & 113.36 & 1.48 & 0.17 \\
\hline
\end{tabular}




\section{Continued}

\begin{tabular}{|c|c|c|c|c|c|c|}
\hline \multirow{10}{*}{ Hydrology } & \multirow{5}{*}{$\begin{array}{c}\text { Topographic } \\
\text { wetness index }\end{array}$} & $<10$ & 157.2 & 259.04 & 1.65 & 0.27 \\
\hline & & $10-20$ & 130.7 & 172.44 & 1.32 & 0.05 \\
\hline & & $20-50$ & 76.4 & 73.92 & 0.97 & -0.26 \\
\hline & & $50-100$ & 25.5 & 15.28 & 0.60 & -0.74 \\
\hline & & $>100$ & 35.1 & 12.04 & 0.34 & -1.30 \\
\hline & \multirow{5}{*}{$\begin{array}{l}\text { Drainage density } \\
\qquad\left(\mathrm{km} / \mathrm{km}^{2}\right)\end{array}$} & $<2$ & 55.4 & 50 & 0.90 & -0.33 \\
\hline & & $2-3$ & 118.4 & 114.96 & 0.97 & -0.26 \\
\hline & & $3-3.75$ & 120.0 & 134.72 & 1.12 & -0.11 \\
\hline & & $3.75-4.6$ & 86.6 & 143.96 & 1.66 & 0.28 \\
\hline & & $>4.6$ & 44.9 & 89.6 & 2.00 & 0.47 \\
\hline \multirow{11}{*}{ Human } & \multirow{11}{*}{$\begin{array}{c}\text { Land use and land } \\
\text { cover }\end{array}$} & Level terrace & 17.1 & 6.22 & 0.36 & -1.24 \\
\hline & & Sloping terrace & 18.6 & 22 & 1.18 & -0.06 \\
\hline & & Valley cultivation & 37.3 & 13.32 & 0.36 & -1.26 \\
\hline & & Hardwood forest & 105.0 & 47.96 & 0.46 & -1.01 \\
\hline & & Protected Hardwood forest & 188.8 & 287.92 & 1.53 & 0.20 \\
\hline & & Mixed forest & 14.5 & 5.72 & 0.40 & -1.15 \\
\hline & & Protected mixed forest & 15.4 & 34.32 & 2.22 & 0.57 \\
\hline & & Shrubland & 7.4 & 9.56 & 1.28 & 0.02 \\
\hline & & Grazing land & 2.1 & 4.14 & 1.96 & 0.45 \\
\hline & & Slides and slips & 4.8 & 102.36 & 21.17 & 2.83 \\
\hline & & Sand/gravel/boulders & 14.4 & 0.001 & 0.00 & -2.83 \\
\hline \multirow{6}{*}{ Geology } & \multirow{6}{*}{ Lithological unit } & Quaternary Deposits & 99.0 & 102.28 & 1.03 & -0.19 \\
\hline & & Upper Siwaliks & 56.9 & 0.7 & 1.28 & 0.02 \\
\hline & & Lower Siwaliks & 90.4 & 98.08 & 1.09 & -0.14 \\
\hline & & Middile Siwaliks & 141.4 & 251.44 & 1.78 & 0.35 \\
\hline & & Pre Siwaliks & 30.1 & 4.48 & 0.15 & -2.13 \\
\hline & & Lesser Himalayas & 7.6 & 0.0 & 0.53 & -0.86 \\
\hline
\end{tabular}

Topographical position index (TPI): The TPI is derived from DEM using Jenness (2006) method. This index identifies topographic slope positions as a basis of landform classifications. Many physical and biological processes acting on these landforms influence landslide occurrence. These landforms are upper slope or ridge, middle slope, footslope, open slope or river valley, and incised river or stream. Landslide density was found higher in foot slopes and incised river in the Lalbakaiya watershed induced by toe erosion and undercutting.

Solar radiation: Solar radiation is the quantification of the light environment in the earth's surface, which is strongly influenced by elevation, surface orientation, slope gradient, and slope shape, shadows, and others (Cioban et al., 2013). 
It influences vegetation patterns and dynamics, and landscape morphology in the mountains. The landslide density was found in the areas of lower radiation, which is probably due to pre-existing high moisture content in the soils as well as joints, fissures, and fractures. This makes favorable for an early rise in pore pressure during a rainstorm which triggers slope failures.

\section{2) Hydrological}

Rainfall: The mean annual precipitation is $2040 \mathrm{~mm}$ at Nijgad near foothill, and $2306 \mathrm{~mm}$ at Makawanpur Garhi (Mahabharat range). More than $80 \%$ of rainfall occurs in the four summer monsoon months. Monthly rainfall in July averages nearly $600 \mathrm{~mm}$ and peak extreme one-day rainfall exceeds $200 \mathrm{~mm}$ in July August and September (DHM, 2018). Cloudburst events triggering landslides and flash flood events are frequent. The maximum 24-hour precipitation recorded at Nijgad was $446 \mathrm{~mm}$ in 1993 during the last 45 years, which caused unprecedented damage to life and property in the watershed as well. The recurrence interval of rainfall intensity within 24 hours has been estimated for 1.5, 6, and 18 years is 100,200 , and $300 \mathrm{~mm}$, respectively (PCTMCDB, 2017). Rainfall intensity of $100 \mathrm{~mm} / 24$ hours or more can initiate widespread shallow to deep-seated landslides, debris flow, and flash floods-normal to severe type depending on the fragility of the hillslopes. The Global Circulation Models predict an increase in annual maximum 5-day rainfall will rise by $60 \mathrm{~mm}$ by 2060, under medium to high emissions scenarios

(https://climateknowledgeportal.worldbank.org/country/nepal). Extreme maximum rainfall is the most relevant indicator for landslides and flood production. The models also predict that by the end of the century period there will be an increase in precipitation for all seasons except the pre-monsoon season. The monsoon rainfall is projected to increase by $27.1 \%$ (MoFE, 2019), hence more rainfall induced disasters are expected.

Topographic wetness index (TWI): The upslope contributing area calculated from the DEM can be a proxy expression of the ridgeline, site of residual soil, colluvium concentration and moisture availability, and drainage flow line (Beven \& Kirkby, 1979; Dietrich et al., 1995; Pack et al., 2005). It determines where the slope materials and water is dispersed and where the flow of both water and slope material tends to concentrate. Convergent slopes can be potential areas of colluvium deposits, flow accumulation leading to saturation led debris flow and landslides. The landslide density was found to decreasing in higher wetness index, i.e., more on the divergent slope and less than convergent slope. Note: The topographic indexes were developed in ArcGIS Environment and then were reclassified as natural break intervals (Table 2).

Drainage density: It indicates run-off conditions as well as the degree of dissection of the landscape. The dense network of drainage line indicates high runoff and low infiltration and vice versa. Some experience shows that pore pressure develops due to the high infiltration of rainwater and makes the slope potentially unstable (Doornkamp, 1974; Selby, 1993). On the contrary, one theory states 
that channel head can be the initiator of landslides, particularly on the deeply weathered and thick colluvium mantle slopes (Dietrich \& Dunne, 1978). Such cases are found in the Upper Siwaliks and quaternary parts of Lalbaikaiya watershed on deeply weathered rocks. The landslides incidences were observed high in drainage density above $2.5 \mathrm{~km} / \mathrm{km}^{2}$.

\section{3) Land use and land cover}

A large part of the study area is under forest, followed by cultivated land (Figure 4). Land use and land cover play an important role in the stability of the slopes. The slopes are mostly unstable on the barren areas provided the geology of the area is also unfavorable (LRMP, 1986). Forest cover prevents the rocks from being exposed to the sun and water, which ultimately reduces the grade of weathering in rocks. Vegetation grabs the topsoil and prevents the drop strike of intense raindrops on the earth's ground. They control slope stability by mechanically reinforcing slopes through plant roots, modifying soil moisture distribution, and pore water pressures (Bishop \& Stevens, 1964; Gray, 1970). Nevertheless, the management of slopes through appropriate cultivation, drainage management, and watershed conservation practices reduces slope failures. Landslide frequency was found to be high in shrubland and the hardwood forest of the Siwaliks. In the Siwaliks, where bedrocks are very fragile, a load of hardwood

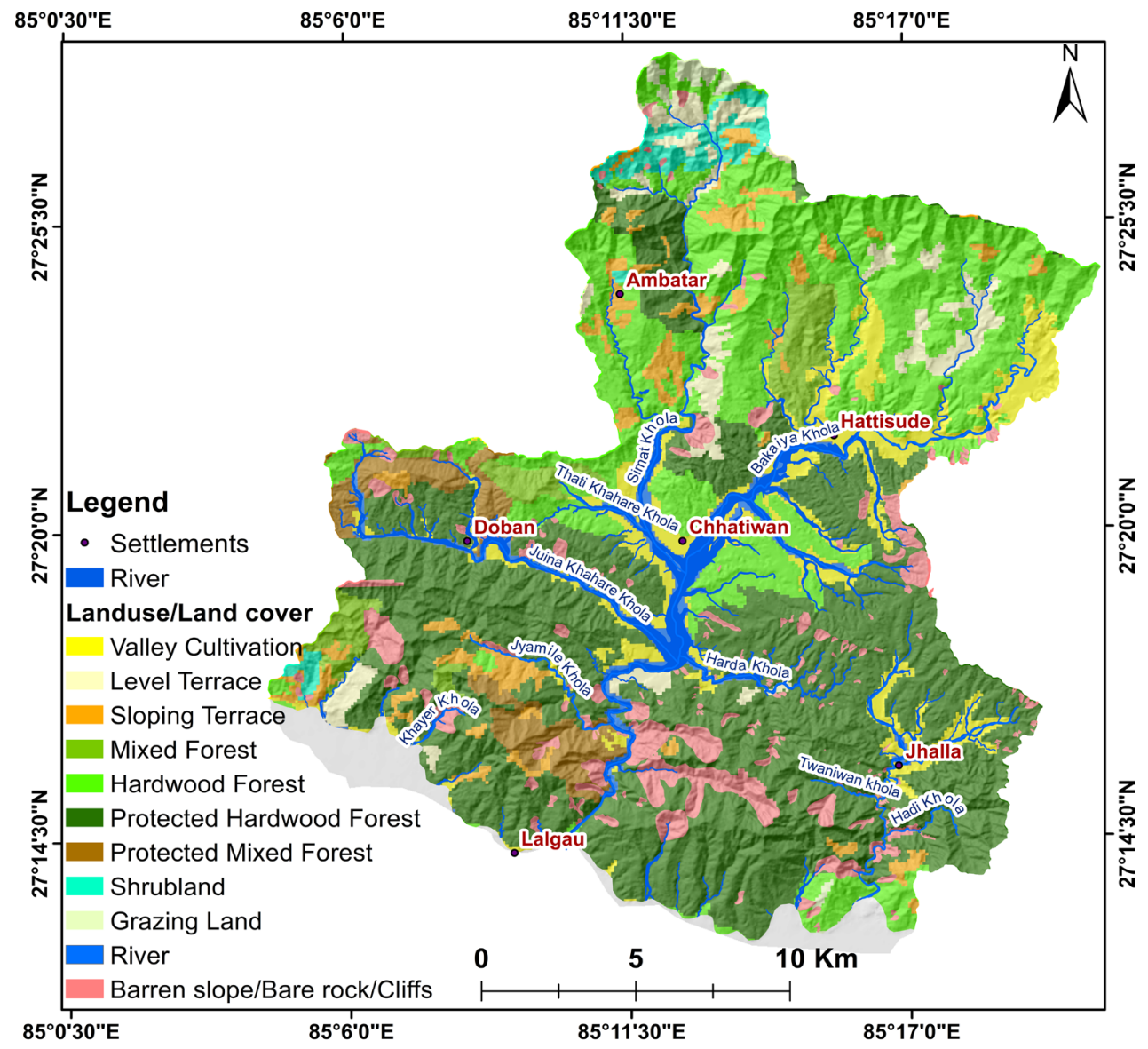

Figure 4. Land use and land cover. 
trees and hydraulic conductivity induced by roots of the trees that penetrate in the fractured rocks during rainstorm reduces the shear strength of the slope and cause numerous slope failures.

Land use and land cover and demographic change: There has been a significant change in land use and land cover in the watershed. Forests and shrubs coverage has declined from 81 percent in 1993 to 75 percent in 2014 (Timalsina et al., 2014). After the eradication of malaria in 1956, people started to migrate to Chure, Bhabar, and the Dun Valley on a large scale. Population density has increased by 7.8 times in Makawanpur District. This encroachment of forest and flood hazard areas for settlement and cultivation as well as overgrazing of livestock coincidence by frequent forest fires has intensified landslide, runoff, and increasing the frequency and magnitude of flash floods.

\section{4) Geology and siesmicity}

Geology and its relation to landslides have been discussed in the above section (Figure 3). Nepal is located at the boundary between Indian and Tibetan tectonic plates and, therefore, lies in a seismically active region, hence earthquakes are frequent. An earthquake is itself a geohazard but can also cause secondary and tertiary geohazards (induced geohazards) through chains or cascades of hazardous processes, such as landslides and mass flows, and landslide dam outbursts. The historical intensity of the earthquake in the watershed has been recorded as moderate-intensity (V) to strong (VI) type (DMG, 2007). Several active faults including Main Boundary Thrust (MBT), Marine Khola Thrust, and Main Frontal Thrust traverse through this watershed which produces frequent seismic waves and causes upliftment $(20 \pm 3 \mathrm{~mm} /$ year $)$ of the terrain, thereby triggering landslides and erosion (Lavé \& Avouac, 2001).

\section{Landslide Susceptibility Mapping}

Following the approaches mentioned above, landslides susceptible maps were prepared (Figure 5). Geomorphic interpretation based susceptible maps reveal susceptible landscape units where past present landslides or erosional scars are frequent, and severe gully and river erosion is observed. The southern part of the watershed, which is an active fold zone (Lavé \& Avouac, 2001) is a prevailingly high landslide area. Similarly, the Juina Khahare Khola watershed also demonstrates high landslide susceptibility. Apart from that the areas under Quaternary and Upper Siwalik despite fewer landslides are highly erodible, where subsequent debris flow and minor landslide like scars due to erosion are common. Hence the whole of this terrain $(32.7 \%, 139.08 \mathrm{sq} \mathrm{km}$ of the total area) is highly susceptible to erosion and slope failures.

These landscape units demonstrate a high spatial probability of landslides occurrence than other areas. Susceptibility evaluation is mainly guided by landslide inventory. This inventory driven approach has high interpretation reliability of landslide susceptible areas but has low predictability of the landslides occurrence, where landslides are not detected, yet could be an area of potential landslides due to the influences of conditioning and triggering factors. Further, be- 
cause of the subjectivity, the geomorphic approach of landslides susceptibility mapping is not much appropriate in showing the spatially varying probability of landslides occurrence.

Similarly, the landslide susceptibility map was prepared for the Lalbakaiya watershed using the GIS-based landslide index method. The assessment showed that $25.8 \%, 22.3 \%, 20.4 \%, 18.0 \%$, and $13.5 \%$ of the watershed is in very low, low, moderate, high, and very landslide susceptible areas respectively. Similarly, the success rate was evaluated using the area under the curve method on the susceptibility map versus new landslide and was found to be $81.55 \%$ (Table 3). Thus the results are very much convincing for the mountainous terrain of the study area (Figure 6 and Figure 7).

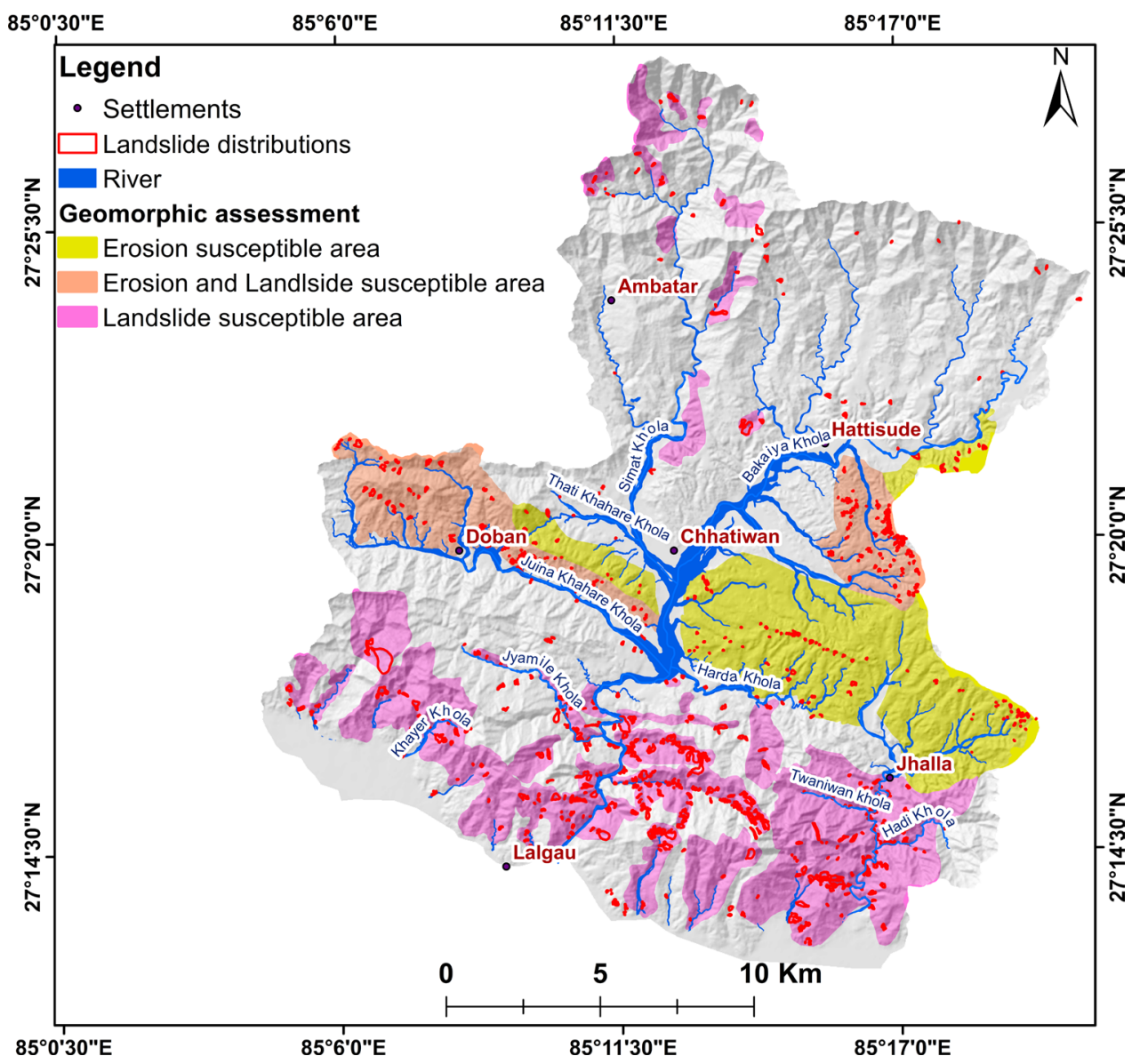

Figure 5. Landslide susceptibility map prepared from the geomorphic approach.

Table 3. Landslide validation.

\begin{tabular}{ccc}
\hline Landslide susceptibility & Area (\%) & \% of validation landslide \\
\hline Very Low & 25.8 & 0.6 \\
Low & 22.3 & 4.5 \\
Moderate & 20.4 & 11.0 \\
High & 18.0 & 30.9 \\
Very High & 13.5 & 53.2 \\
\hline
\end{tabular}




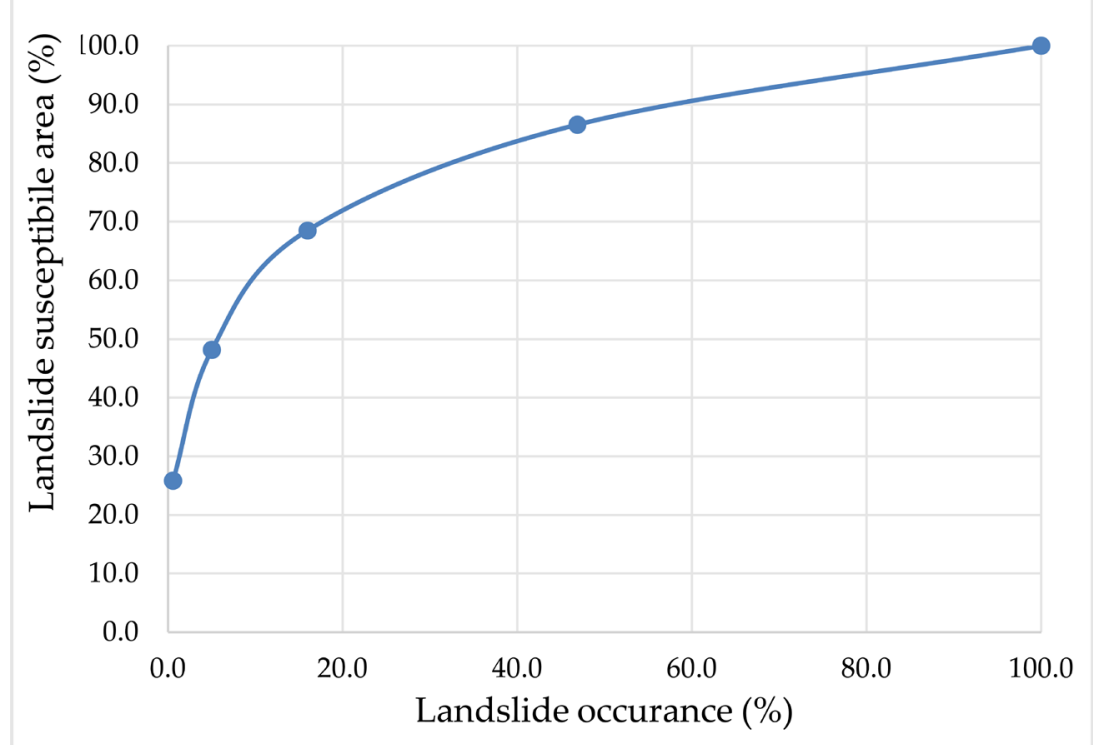

Figure 6. Success rate evaluation of landslide susceptible map prepared by using the landslide index method.

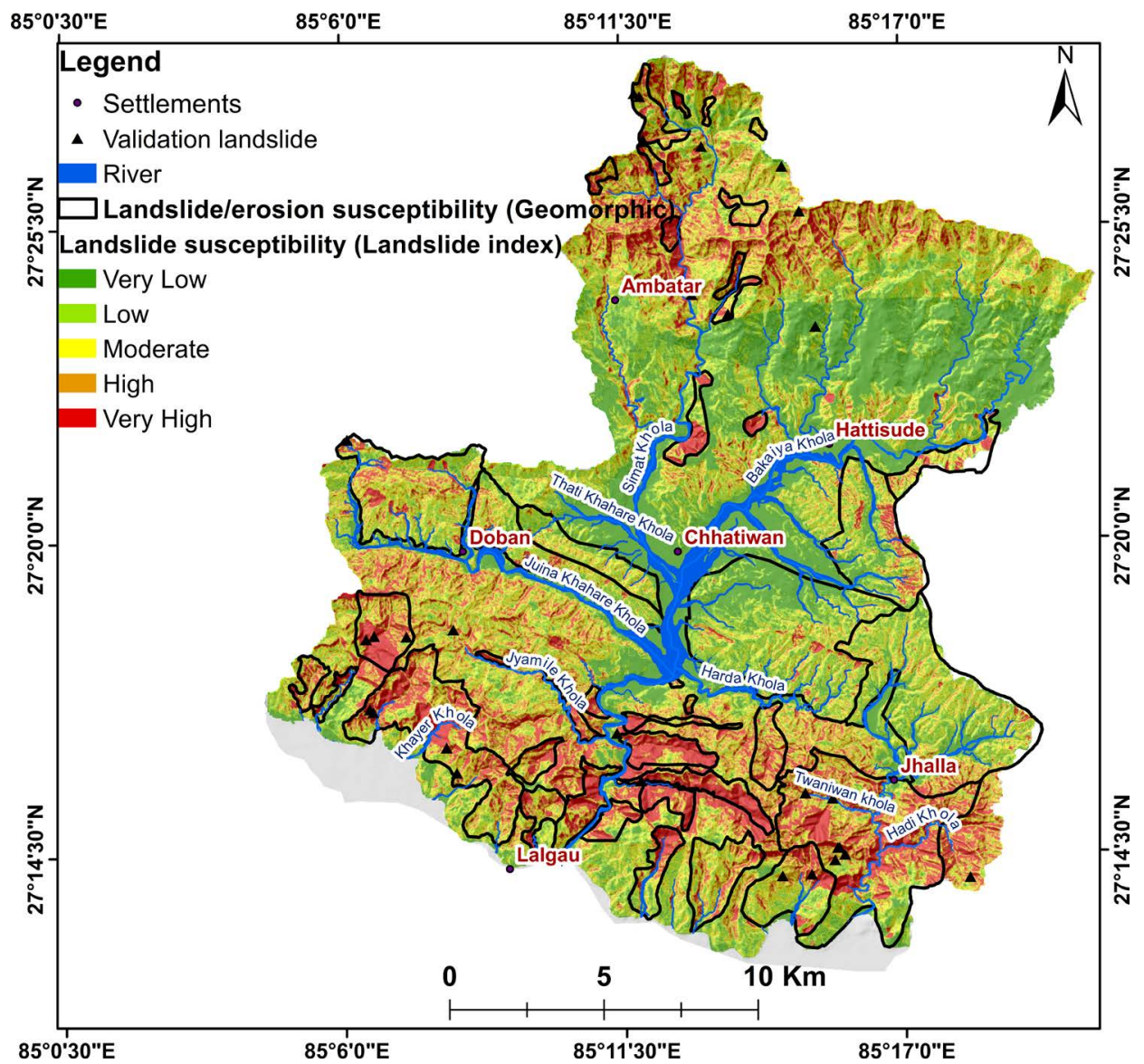

Figure 7. Landslide susceptible map (Landslide index method) of Lalbakaiya Watershed.

In contrast to the geomorphic approach, the landslide index approach is an objective method of assessing landslide potential areas considering observable 
landslide relationship with the geo-ecological factors discussed above. Areas of higher landslide susceptibility map derived from the landslide index method fairly conform with that derived from the geomorphic approach. Unlike, geomorphic approach (where landslide susceptibility areas are characterized by landscape unit), landslide susceptibility derived from the landslide index method is represented by each pixel value that indicates the probability of landslides occurrence. The susceptibility map is, therefore, amenable to regroup into various susceptible classes. Further landslide index model can predict areas of landslides based on quantitative relation between landslides and the afore discussed factors. For example, the landslides were less observed in the Lesser Himalayan slopes, nevertheless, the model detected this part as a highly susceptible area, which is in fact, most likely. The limitation of this approach is that these susceptibility areas do not represent clearly defined landscape units, which can be the basis for land use and development planning and disaster risk reduction. The pixel-based map output is relatively messy and variable in a short distance. Similarly, the model has overlooked highly erodible areas of Quaternary and Upper Siwaliks, where landslides not apparent despite severe erosion and numerous minor failures.

Hence, both approaches can be integrated to produce predictable, reliable, and applicable landslide susceptibility maps.

\section{Conclusion}

Landslide of the Lalbakaiya watershed is primarily controlled by geology representing young, weak, and fragile sedimentary rocks. Besides the role of topography such as steep slope, high relative relief, and land use was found to be important in determining the landslide and erosion susceptibility. These processes are triggered by monsoon precipitation, seismicity, and land use change in addition to other factors. These geomorphic processes and their intensity in hill catchment have as implication on the flash flood, bank erosion, river shift, and course change, and inundation events in the low.

Landslide susceptibility assessment was performed using the geomorphic and statistical index and both approaches have produced similar results. The susceptible map produced from the Geomorphic approach is simple and easy to communicate with the community, practitioners, and planners thus can fruitfully be used in participatory planning such as disaster risk management. Prioritization for mitigation and conservation on a larger scale can be assessed efficiently through this technique. However, this approach is qualitative and may not render a consistent result, and the reliability of the result depends upon the knowledge and skill of the expert. On the other hand, the statistical method generates consistent and reliable results and therefore can quantitatively be evaluated in terms of varying degrees of susceptibility. The limitation of this approach is that these susceptible areas do not represent clearly defined landscape units, and can also overlook highly erodible areas where landslides are not apparent despite severe erosion and numerous minor failures. 
The study confirms that both geomorphic and statistical approaches can be complementarily integrated to produce predictable, reliable, and applicable landslide susceptibility maps that can make a plausible planning tool for conservation, development, and disaster risk reduction in the populated slopes of the Himalayas and like.

Except for high erodible quarternary underlain areas, both susceptibility maps showed the approximately similar location and extent of high landslide susceptibility areas.

Lastly, landslide susceptibility maps revealed that the southern part of the watershed is highly vulnerable to landslides, which can be attributed to fragile geology, active tectonics, steep and rugged topography, and high rainfall.

\section{Recommendations}

- The geomorphic approach of landslide susceptibility assessment needs to incorporate geo-engineering properties of the hillslope materials and form, and geo-hydrological processes operating on the hillslopes. This will increase accuracy, and thus approval and recognition from the user and scientific community.

- Similarly in the absence of geo-technical surveys, the simple and economic statistical method is a viable alternative approach to susceptibility assessment. But it needs to be used in combination with that of the geomorphic approach.

- Such landslide susceptibility maps can be fruitfully used by the government agencies and various stakeholders working in soil conservation, watershed management, disaster risk management.

- Landslide mitigation actions such as bio-engineering along with land cover management approaches can be implemented. Some landcover management strategies are afforestation in degraded land, forest conservation, and less tillage farming on steep land, gully treatment on the hillslope, and many others.

\section{Conflicts of Interest}

The authors declare no conflicts of interest regarding the publication of this paper.

\section{References}

Anis, Z., Wissem, G., Vali, V., Smida, H., \& Essghaier, G. M. (2019). GIS-Based Landslide Susceptibility Mapping Using Bivariate Statistical Methods in North-Western Tunisia. Open Geosciences, 11, 708-726. https://doi.org/10.1515/geo-2019-0056

Baum, R. L., Miyagi, T., Lee, S., \& Trofymchuk, O. M. (2014). Introduction: Hazard Mapping. In Landslide Science for a Safer Geoenvironment (pp. 395-396). Berlin: Springer. https://doi.org/10.1007/978-3-319-05050-8_61

Beven, K. J., \& Kirkby, M. J. (1979). A Physically-Based Variable Contributing Area Model of Basin Hydrology. Hydrological Sciences Bulletin, 24, 43-69.

https://doi.org/10.1080/02626667909491834 
Bhandari, P. B., \& Dhakal, S. (2018). Lithological Control on Landslide in the Babai Khola Watershed, Siwaliks Zone of Nepal. American Journal of Earth Sciences, 5, 54-64.

Bishop, D. M., \& Stevens, M. E. (1964). Landslide on Logged Area in Southeast Alaska. US Dep. Agric For. Serv Res. Paper.

Brunsden, D., Doornkamp, J. C., Fookes, P. G., Jones, D. K., \& Kelly, J. M. (1975). Large Scale Geomorphological Mapping and Highway Engineewing Design. Quarterly Journal of Engineering Geology, 8, 227-253. https://doi.org/10.1144/GSL.QJEG.1975.008.04.01

CBS (2011). National Population and Housing Census 2011 (National Report). Kathmandu: Central Bureau of Statistics.

Chapin, F. S., Matson, P. A., \& Mooney, H. A. (2002). Principles of Terrestrial Ecosystem Ecology. New York: Springer. https://doi.org/10.1007/b97397

Cioban, A., Criveanu, H., Matei, F., Pop, I., \& Rotaru, A. (2013). Aspects of Solar Radiation Analysis Using ArcGis. Bulletin UASVM Horticulture, 70, 437-440.

Crozier, M. J. (1986). Landslides: Causes, Consequences and Environment. London: Croom Helm Australia Pty. Ltd.

Cruden, D. M. (1991). A Simple Definition of a Landslide. Bulletin of the International Association of Engineering Geology, 43, 27-29. https://doi.org/10.1007/BF02590167

Cruden, D. J., \& Varnes, D. J. (1996). Landslide Types and Process. In A. K. Turner, \& R. L. Schuster (Eds.), Landslides: Investigations and Mitigation (pp. 36-75). Washington DC: Transportation Research Board, US National Academy of Sciences.

Dahal, R. K., Hasegawa, S., Nonomura, A., Yamanaka, M., Dhakal, S., \& Paudyal, P. (2008). Predictive Modelling of Rainfall-Induced Landslide Hazard in the Lesser Himalaya of Nepal Based on Weights-of-Evidence. Geomorphology, 102, 496-510. https://doi.org/10.1016/j.geomorph.2008.05.041

Dai, F. C., Lee, C. F., Li, J., \& Xu, Z. W. (2001). Assessment of Landslide Susceptibility on the Natural Terrain of Lantau Island, Hong Kong. Environmental Geology, 40, 381-391. https://doi.org/10.1007/s002540000163

Deoja, B. B., \& Thapa, B. (1991). Transportation Economics: Generalized Heuristics. In B. B. Deoja, M. Dhital, B. Thapa, \& A. Wagner (Eds.), Mountain Risk Engineering Handbook (p. 557). Kathmandu: ICIMOD.

Dhakal, S. (2015). Evolution of Geomorphologic Hazards. In H. K. Nibanupudi, \& R. Shaw (Eds.), Mountain Hazards and Disaster Risk Reduction (pp. 53-72). Berlin: Springer. https://doi.org/10.1007/978-4-431-55242-0_4

Dhakal, S., Adhikari, S., \& Adhikari, S. (2014). Geological Characteristics. In CDES (Ed.), Hazard and Vulnerability Analysis of Nepal's Chure Area (30-60). Kathmandu: Central Department of Environmental Science, Tribhuvan University for Ministry of Forest and Soil Conservation, GoN.

Dhital, M. R. (2015). Geology of the Nepal Himalaya: Regional Perspective of the Classic Collided Orogen. Berlin: Springer. https://doi.org/10.1007/978-3-319-02496-7

Dhital, M. R., Upreti, B. N., Dangol, V., Bhandari, A. N., \& Bhattarai, T. N. (1991). Geological Engineering Methods Applied in Mountain Road Survey: An Example from Baitadi-Darchula Road Project, Nepal. Journal of Nepal Geological Society, 7, 49-67.

Dhital, M. (2003). Causes and Consequences of the 1993 Debris Flows and Landslides in the Kulekhani Watershed, Central Nepal. In D. Rickenmann, \& C.-L. Chen (Eds.), Proceedings of the 3rd International Conference on Debris-Flow Hazards Mitigation: Mechanics, Prediction and Assessment (931-942). Rotterdam: Millpress. 
DHM (2018). Meteorological Data. Kathmandu: Department of Hydrology and Meteorology.

Dietrich, W. E., \& Dunne, T. (1978). Sediment Budget for a Small Catchment in Mountainous Terrain. Zeitschrift für Geomorphologie, 29, 191-206.

Dietrich, W. E., Reiss, R., Hsu, M. L., \& Montgomery, D. R. (1995). A Process-Based Model for Colluvial Soil Depth and Shallow Landsliding Using Digital Elevation Data. Hydrological Processes, 9, 383-400. https://doi.org/10.1002/hyp.3360090311

Dikau, R., Cavallin, A., \& Jäger, S. (1996). Databases and GIS for Landslide Research in Europe. Geomorphology, 15, 227-239. https://doi.org/10.1016/0169-555X(95)00072-D

Doornkamp, J. C. (1974). Tropical Weathering and the Ultra-Microscopic Characteristics of Regolith Quartz on Dartmoor. Geografiska Annaler. Series A, Physical Geography, 56, 73-82. https://doi.org/10.2307/520428

Dou, J., Yamagishi, H., Zhu, Z., Yunus, A. P., \& Chen, C. W. (2018). TXT-Tool 1.081-6.1 A Comparative Study of the Binary Logistic Regression (BLR) and Artificial Neural Network (ANN) Models for GIS-Based Spatial Predicting Landslides at a Regional Scale. In Landslide Dynamics: ISDR-ICL Landslide Interactive Teaching Tools (pp. 139-151). Berlin: Springer. https://doi.org/10.1007/978-3-319-57774-6_10

DWIDP (2019). Disaster Review 1973 to 2016. Kathmandu: Department of Water Induced Disaster Management, Ministry of Home Affairs, Government of Nepal.

DMG (2007). Geological Maps of Exploration Block 1-10. Kathmandu: Department of Mines and Geology, Petroleum Promotion Exploration Project.

Ercanoglu, M., Gokceoglu, C., \& Van Asch, T. W. (2004). Landslide Susceptibility Zoning North of Yenice (NW Turkey) by Multivariate Statistical Techniques. Natural Hazards, 32, 1-23. https://doi.org/10.1023/B:NHAZ.0000026786.85589.4a

Felicísimo, Á. M., Cuartero, A., Remondo, J., \& Quirós, E. (2013). Mapping Landslide Susceptibility with Logistic Regression, Multiple Adaptive Regression Splines, Classification and Regression Trees, and Maximum Entropy Methods: A Comparative Study. Landslides, 10, 175-189. https://doi.org/10.1007/s10346-012-0320-1

Ghimire, M. (2001). Geo-Hydrological Hazard and Risk Zonation of Banganga Watershed Using GIS and Remote. Journal of Nepal Geological Society, 23, 99-110.

Ghimire, M. (2011a). Geomorphological Studies on the First-Order Basins in the Siwalik Hills, Nepal. Sapporo: Unpublished Doctoral Dissertation, Hokkaido University.

Ghimire, M. (2011b). Landslide Occurrence and Its Relation with Terrain Factors in the Siwalik Hills, Nepal: Case Study of Susceptibility Assessment in Three Basins. Natural Hazards, 56, 299-320. https://doi.org/10.1007/s11069-010-9569-7

Ghimire, M. (2020). Landscape Characteristics and Cultural Process in the Siwalik Hills: A Geographical Perspective. In Studies in Nepali History and Society (pp. 59-109). Kathmandu: Mandala Book Point.

Gray, D. H. (1970). Effects of Forest Clear-Cutting on the Stability of Natural Slopes. Bulletin of Association of Engineering Geologists, 7, 45-66.

Guzzetti, F., Carrara, A., Cardinali, M., \& Reichenbach, P. (1999). Landslide Hazard Evaluation: A Review of Current Techniques and Their Application in a Multi-Scale Study, Central Italy. Geomorphology, 31, 181-216. https://doi.org/10.1016/S0169-555X(99)00078-1

Guzzetti, F., Malamud, B. D., Turcotte, D. L., \& Reichenbach, P. (2002). Power-Law Correlations of Landslide Areas in Central Italy. Earth and Planetary Science Letters, 195, 169-183. https://doi.org/10.1016/S0012-821X(01)00589-1 
Guzzetti, F., Mondini, A. C., Cardinali, M., Fiorucci, F., Santangelo, M., \& Chang, K. T. (2012). Landslide Inventory Maps: New Tools for an Old Problem. Earth-Science Reviews, 112, 42-66. https://doi.org/10.1016/j.earscirev.2012.02.001

Hutton, J. X. (1788). Theory of the Earth; or an Investigation of the Laws Observable in the Composition, Dissolution, and Restoration of Land upon the Globe. Earth and Environmental Science Transactions of the Royal Society of Edinburgh, 1, 209-304. https://doi.org/10.1017/S0080456800029227

Hungr, O., Leroueil, S., \& Picarelli, L. (2014). The Varnes Classification of Landslide Types, an Update. Landslides, 11, 167-194. https://doi.org/10.1007/s10346-013-0436-y

Highland, L. M., \& Bobrowsky, P. (2008). The Landslide Handbook-A Guide to Understanding Landslides. Reston, Virginia, CO: U.S. Geological Survey (USGS) National Landslide Information Center (NLIC). https://doi.org/10.3133/cir1325

Jaiswal, P., \& van Westen, C. J. (2009). Estimating Temporal Probability for Landslide Initiation along Transportation Routes Based on Rainfall Thresholds. Geomorphology, 112, 96105. https://doi.org/10.1016/j.geomorph.2009.05.008

Jenness, J. (2006). Topographic Position Index (tpi_jen.avx) Extension for ArcView 3.x, v.1.3a. http://www.jennessent.com/arcview/tpi.htm

Korup, O., Densmore, A. L., \& Schlunegger, F. (2010). The Role of Landslides in Mountain Range Evolution. Geomorphology, 120, 77-90.

https://doi.org/10.1016/j.geomorph.2009.09.017

Laban, P. (1979). Landslide Occurrence in Nepal. IWM/WP.

Lavé, J., \& Avouac, J. P. (2001). Fluvial Incision and Tectonic Uplift across the Himalayas of Central Nepal. Journal of Geophysical Research, 106, 26561-26591. https://doi.org/10.1029/2001JB000359

Lee, S., \& Pradhan, B. (2006). Probabilistic Landslide Hazards and Risk Mapping on Penang Island, Malaysia. Earth System Science, 115, 661-672.

Lee, S., Ryu, J. H., Lee, M. J., \& Won, J. S. (2003). Use of an Artificial Neural Network for Analysis of the Susceptibility to Landslides at Boun, Korea. Environmental Geology, 44, 820-833. https://doi.org/10.1007/s00254-003-0825-y

LRMP (1986). Land Capability Report. Kathmandu: Land Resource Mapping Project, Kenting Earth Science.

MoFE (2019). Climate Change Scenarios for Nepal for National Adaptation Plan (NAP). Kathmandu: Ministry of Forests and Environment.

Mandal, S., \& Mondal, S. (2019). Statistical Approaches for Landslide Susceptibility Assessment and Prediction. Berlin: Springer.

https://doi.org/10.1007/978-3-319-93897-4

Miyagi, T., Gyawali, B. P., Tanavud, C., Potichan, A., \& Hamasaki, E. (2004). Landslide Risk Evaluation and Mapping.

Pachauri, A., \& Pant, M. (1992). Landslide Hazard Mapping Based on Geological Attributes. Engineering Geology, 32, 81-100. https://doi.org/10.1016/0013-7952(92)90020-Y

Pack, R. T., Tarboton, D. G., Goodwin, C. N., \& Prasad, A. (2005). SINMAP UserGs Manual. Logan, UT: Utah State University.

Park, S., Choi, C., Kim, B., \& Kim, J. (2013). Landslide Susceptibility Mapping Using Frequency Ratio, Analytic Hierarchy Process, Logistic Regression, and Artificial Neural Network Methods at the Inje Area, Korea. Environmental Earth Sciences, 68, 1443 1464. https://doi.org/10.1007/s12665-012-1842-5 
PCTMCDB (2017). President Chure-Tarai Madhesh Conservation and Management Master Plan. Kathmandu: President Chure-Tarai Madhesh Conservation and Development Board.

Pradhan, A. M., \& Kim, Y. T. (2014). Relative Effect Method of Landslide Susceptibility Zonation in Weathered Granite Soil: A Case Study in Deokjeok-ri Creek, South Korea. Natural Hazards, 72, 1189-1217. https://doi.org/10.1007/s11069-014-1065-Z

Pradhan, B., \& Lee, S. (2010). Landslide Susceptibility Assessment and Factor Effect Analysis: Backpropagation Artificial Neural Networks and Their Comparison with Frequency Ratio and Bivariate Logistic Regression Modelling. Environmental Modelling \& Software, 25, 747-759. https://doi.org/10.1016/j.envsoft.2009.10.016

Pradhan, A. M. S., Lee, S. R., \& Kim, Y. T. (2019). A Shallow Slide Prediction Model Combining Rainfall Threshold Warnings and Shallow Slide Susceptibility in Busan, Korea. Landslides, 16, 647-659. https://doi.org/10.1007/s10346-018-1112-z

Reichenbach, P., Rossi, M., Malamud, B., Mihri, M., \& Guzzetti, F. (2018). A Review of Statistically-Based Landslide Susceptibility Models. Earth-Science Reviews, 180, 60-91. https://doi.org/10.1016/j.earscirev.2018.03.001

Selby, M. J. (1993). Hillslope Materials and Processes (2nd ed.). Oxford: Oxford University Press.

Shrestha, A. B., \& Bajracharya, S. R. (2013). Case Studies on Flash Flood Risk Management in the Himalayas: In Support of Specific Flash Flood Policies. Kathmandu: ICIMOD.

Stocking, M. A. (1972). Relief Analysis and Soil Erosion in Rhodesia Using Multivariate Techniques. Zeitschrift für Geomorphologie, 16, 432-443.

Terzaghi, K. (1950). Geologic Aspects of Soft-Ground Tunneling. Hoboken, NJ: John Wiley \& Sons, Incorporated.

Timalsina, N., Maharjan, N., Giri, S. R., Acharya, D., \& Bhuju, D. R. (2014). Land Use and Land Cover Pattern and Change. In CDES (Ed.), Hazard and Vulnerability Analysis of Nepal's Chure Area (183-184). Kathmandu: Central Department of Environmental Science, Tribhuvan University for Ministry of Forest and Soil Conservation, GoN.

Trigila, A., Frattini, P., Casagli, N., Catani, F., Crosta, E., Ladanza, C., Lari, S. et al. (2013). Landslide Susceptibility Mapping at National Scale: The Italian Case Study. In C. Margottini (Ed.), Landslide Science and Practice (pp. 287-295). Berlin: Springer-Verlag. https://doi.org/10.1007/978-3-642-31325-7_38

Van Westen, C. J. (2000). The Modelling of Landslide Hazards Using Gis. Surveys in Geophysics, 21, 241-255. https://doi.org/10.1023/A:1006794127521

Van Westen, C. (1997). Statistical Landslide Hazard Analysis ILWIS 2.1 for Windows Application Guide. Enschede: ITC Publication.

Van Westen, C. J., Castellanos, E., \& Kuriakose, S. L. (2008). Spatial Data for Landslide Susceptibility, Hazard, and Vulnerability Assessment: An Overview. Engineering Geology, 102, 112-131. https://doi.org/10.1016/j.enggeo.2008.03.010

Varnes, D. J. (1958). Landslide Types and Processes. Landslides and Engineering Practice, 24, 20-47.

Varnes, D. J. (1978). Slope Movement Types and Process. In R. L. Schuster, \& R. J. Krizek (Eds.), Landslide, Analysis and Control Special Report 176 (pp. 11-33). Washington DC: Transportation Research Board, National Academy of Sciences.

Wagner, A. (1983). The Principal Geological Factors Leading to Landslides in the Foothills of Nepal: A Statistical Study of 100 Landslides-Steps for Mapping the Risk of Landslides (p. 58). HELVETAS-Swiss Technical Cooperation and ITECO-Company for International Cooperation and Development, Unpublished. 
Yang, Y., Yang, J., Xu, C., \& Song, C. (2019). Local-Scale Landslide Susceptibility Mapping Using the B-GeoSVC Model. Landslides, 16, 1301-1312.

https://doi.org/10.1007/s10346-019-01174-y

Youssef, A. M., Pradhan, B., Jebur, M. N., \& El-Harbi, H. M. (2015). Landslide Susceptibility Mapping Using Ensemble Bivariate and Multivariate Statistical Models in Fayfa Area, Saudi Arabia. Environmental Earth Sciences, 73, 3745-3761. https://doi.org/10.1007/s12665-014-3661-3

Zhang, Y., Lan, H., Li, L., Wu, Y., Chen, J., \& Tian, N. (2020). Optimizing the Frequency Ratio Method for Landslide Susceptibility Assessment: A Case Study of the Caiyuan Basin in the Southeast Mountainous area of China. Journal of Mountain Science, 17, 340-357. https://doi.org/10.1007/s11629-019-5702-6 